\title{
REGIONAL TREASURY CENTRES IN SOUTH EAST ASIA - THE CASE OF BRUNEI DARUSSALAM
}

\author{
Petr Polak \\ Rady Roswanddy Roslan ${ }^{* *}$
}

Received: 17. 11. 2008

Accepted: 15. 4. 2009

\author{
Professional paper \\ UDC 339.7(5-12)
}

The paper investigates the location criteria (LC) considered when establishing regional treasury centres (RTCs) across three countries: Brunei, Singapore and Hong Kong. LC are the important factors that are compulsory for multinational corporations (MNCs) to examine before setting up RTCs in another region other than where their headquarters are. Comparing Brunei to Asia's leading international financial centre and location for RTCs i.e. Singapore and Hong Kong would assist in identifying whether Brunei can host RTCs. The study contributes to the understanding of LC assessment before establishing a RTC in any location. A similar investigation method, conducted previously and applied to European countries, is duplicated and applied to the three Asian countries. The results found that compared to Singapore and Hong Kong, Brunei is lacking in terms of the examined LC.

\section{INTRODUCTION}

Giegerich et al. (2002) and Treasury Today: European Cash Management a practical guide (2007) defines TC as a "centralized treasury management function which is legally structured as a separated group or as a branch and is normally located in a tax efficient environment". "Tax efficient" basically means a location that offers beneficial tax regimes (e.g. low percentage tax incurred to MNCs) compared to another location. Blair (1999) reaffirms the

\footnotetext{
* Dr. Petr Polak, Faculty of Economics, VSB - Technical University of Ostrava, Czech Republic, and Faculty of Business and Enterprise, Swinburne University of Technology, Melbourne, Australia, Phone: +420-737-824570, Email: petr.polak@vsb.cz

** Rady Roswanddy Roslan, student of finance, supervised by Dr. Petr Polak, at the Swinburne University of Technology.
} 
importance of tax system; when Nokia faced the apparent need to be close to its international operation in Singapore, it considered setting up a RTC in Singapore, Hong Kong, Malaysia and Australia (Giumarra, 2001). Due to unattractive tax systems offered by Hong Kong, Malaysia and Australia, Singapore was chosen. Furthermore, Murphy (2000a) points out that RTCs or International TCs are primarily tax driven where tax on profits generated is at a favorable rate. The world's largest package and document delivery company UPS considered Singapore and the Philippines to locate their RTC, as these two countries offered some of the lowest tax rates in Asia. UPS decided on Singapore (Chang, 2008). Zink et al. (1995) state that TCs are primarily driven by tax savings and also other factors, such as reduced interest expense, elimination of idle cash and lower bank and foreign exchange transaction costs.

\subsection{Functions of treasury centres}

The functions of TC, as defined by Potty et al. (2004), are fourfold: asset and liability management, sales and trading of currency, credit and derivatives products in capital markets, and financial risk management. Fundamentally, TCs provide financial management and transaction services for the other group entities (Geigerich, 2002), that is, the group of subsidiaries located at a different region than the headquarters. Mulligan (2001) explains four elements of treasury management, which comprise the main categories of the functions of TCs: currency risk management (market and credit risk management), funds management, cash management and banking relationships.

\subsection{Treasury centre organization: Structures and models}

The organization of TCs depends on the extent of treasury functions and management the treasurer may choose. The treasurer may choose to manage practical treasury functions, such as liquidity support only, or simply direct the full range of functions, i.e. take on the full range of treasury services discussed by Potty et al. (2004). Geigerich (2002) developed two fundamental models to described treasury management organization. In the first model, TC represents and operates all transactions for the group companies, while, in the other model, it acts as the group's central in-house clearing bank. Mulligan (2001) describes treasury management organization as two extremes: centralized and decentralized. The performance of centralized and decentralized treasury managements has a statistically significant difference in raising the efficiency of regional treasury centres (RTCs) (Mulligan, 2001). 
Murphy (2000a) simplifies TC organization structure as one US headquarters with one or more RTCs under its control. RTCs provide services under the group policy to the group entities located in their region (Murphy, 2000a). TC organization is structured according to the requirements of underlying business operations. Basically, the extent of functions and services of TC depends on the business operations.

As more companies expand operations across international borders, erratic behavior of the international financial market entails standardization of international payments, as the simplification of fund movements becomes the extended challenge for corporate treasury (Giegerich, 2002). Corporate treasury is required to be more aware of the volatility of the international financial market and conversant with current payment standards practiced by other corporate treasuries, in order to keep up with international trends. These challenges are key influencers of corporate treasury to the extent of provision of functions and practicality of management organization.

Corporate treasuries face problems with treasury functions that have to be performed and the degree of (de)centralization. The decision making is greatly influence by these challenges. The complexities of TC organization is of crucial importance for understanding different structures and models developed by other studies based on common MNC practice. Potty et al. (2004) suggested four models related to the range of functions and degree of managerial (de)centralization.

\subsection{Criteria influencing location of RTCs: Location criteria (LC)}

As mentioned previously, perhaps the most important factor or criterion when considering the location of RTCs is the tax system or regime of the location being considered. Ross (1990, cited in Mulligan, 2001) describes that, from a multinational corporation perspective, tax considerations and treasury issues are closely related. Simkova (2005, cited in Polak et al. 2007) establishes the criteria i.e. the requirements/conditions that need to be considered in setting up an international treasury centre (ITC) for a holding company in Czech Republic. The criteria are: bank transaction fees (minimum), prices for foreign incoming and outgoing payments (minimum), withholding and corporate tax (minimum), withholding tax for intra-group yield (minimum), reporting requirements (minimum), rating (as good as possible), currency environment and existence of other TCs in the region. Simkova (2005, cited in Polak et al. 2007) found that Switzerland leads in the mentioned criteria, when tested with 
the other countries, mostly European Union member states, such as Germany, Ireland, Italy, Slovakia and United Kingdom.

Levieux (2007) compared Singapore and Hong Kong, in the attempt to determine which country would provide better financial facilities for MNCs, looking to set up RTCs in Asia. The outcome was favorable for both countries, because when two different structured TC organizations were presented, one would operate better in Hong Kong, while the other would be more efficient in Singapore (Levieux, 2007). The counterpart model TC presented by Levieux (2007) operates better for MNCs in Singapore than in Hong Kong ,because of Hong Kong's restriction on deductibility of interest expense. The interest payable to an entity that is not subject to Hong Kong's income tax is not deductible for tax purposes; hence it is impractical to consider a Hong Kong as a vehicle for incorporation. However, Levieux (2007) argues that, if a TC operates mainly as an agent for the underlying operating entities, Singapore's advantage over Hong Kong would reduce significantly. Different financial regulations provided by different locations will suit differently structured TCs.

MNCs embarking on setting up RTCs in Asia tend to put Singapore and Hong Kong on the top of their lists of locations (Levieux, 2007). Levieux (2007) reasons that the popularity of these two countries, is due to "their roles as international financial centre, solid telecommunications and transport infrastructures, easy availability of qualified staff, loose foreign exchange controls and their benign tax environments". The debate to locate regional headquarters (RHQs) in Asia is frequently between Singapore and Hong Kong (Business Asia, 1999). A survey conducted on choice of location for RHQs by MNCs shows 35 percent of respondents choosing Hong Kong, followed by 30 percent in favor of Singapore, nine percent of Tokyo, and five percent of Sydney (Business Asia, 2000).

Murphy (2000b) examined the non-tax criteria involved when making decisions to locate RTCs. The non-tax criteria are cost (people, premises, IT and telecoms); outsourced option availability; location of other operations; centres of expertise (high quality treasury expertise); control (whether Directors, CEOs and CFOs are taking direct interest in control of treasury activities); currency control of the Euro; banking system and regulation (availability of modern banking and strong regulation); language (English - prominent financial language) and name recognition (region well known for setting up TCs). Mulligan (2001) suggested very similar criteria in locating a centralised treasury 
Management, Vol. 14, 2009, 1, pp. 77-101

P. Polak, R. R. Roslan: Regional treasury centres in South East Asia - The case of Brunei...

department especially the tax related criteria mentioned in Simkova (2005), as well as non-tax related criteria examined by Murphy (2000b).

Criteria described by Simkova (2005, cited in Polak et al. 2007) will provide the primary list of criteria used in this study. Do these criteria exist or do they need to be improved competitively compared to other locations in the effort to encourage MNCs to set up RTCs or ITCs in Brunei? Simkova (2005, cited in Polak et al. 2007) provided specific list of criteria commonly assessed when considering certain locations for the set up of RTC. These criteria will be referred to as Location Criteria (LC).

Casalino (2001) mentions other LC, such as restrictions for finance companies, license involved in setting up companies in another country, concentration of cash, notional pooling and fees and restrictions for resident/non-resident MNCs. Good access to regional and international affiliates and appropriate time zone, relative to the region of RTCs, are also LC to consider, as suggested by Anwar (1999). Giegerich (2002) points out that access to a major stock exchange, a liberalized capital market, political stability, flexible capitalization rules and double tax treaty networks are also LC to be examined, when considering where to locate a RTC.

Mr. Lee Chuan Teck, the Executive Director, Financial Markets Strategy of Monetary Authority of Singapore, said that "we monitor these trends (MNCs setting up operations in Singapore) closely; constantly reviewing our policies and refining our tax regime, to maintain our status as the location of choice for regional corporate treasuries" (Monetary Authority of Singapore, 2007). Yuthamanop (2004) supports the changes made when new rules were introduced in Thailand, so that MNCs could set up RTCs. Necessary changes to financial and banking regulation are vital to, firstly, draw corporate RTCs into the country, while regular monitoring for updates by the right authorities to maintain beneficial operation of these RTCs is also compulsory for the long term.

\section{FORMULATION OF PROBLEM}

Leow (2005) argued that small changes, rather than big ones, have a significant effect on multinationals in Singapore. The tax concession under the Global Trade Programme was widened in 2006, in order to include trades nominated in Singapore dollar transactions. The requirement for a transferee company to be a Singapore tax resident, in order to obtain stamp duty relief on 
the transfer of assets between associated companies had been removed as of February 2005. In addition, 80 percent export percentage requirement for the Bonded Warehouse Scheme has been lifted, in order to facilitate greater flexibility in storing and moving goods between pre-approved warehouses. These changes Singapore have been made to induce growth of multinationals in the country and the Brunei has potential to do the same. Some of the changes that have already been made include establishing Brunei International Financial Centre (BIFC) to stimulate growth of Brunei as an off-shore financial centre (Oxford Business Group, 2007).

\subsection{Leading international financial centres and hosts for RTCs}

Examining other countries, especially the leading international financial centre and hosts of RTCs, as well as the development of their financial and banking sector, will assist in solving this issue. Through comparative analysis, this study will identify differences and similarities (if available) in the current situation affecting multinationals, especially RTCs and treasury activities, in the three countries involved in study. Thus the differences will form recommendations for Brunei to consider improving upon in achieving desirable treasury performance.

Blair (1999), MAS (2005) and Levieux (2007) have made it clear that Singapore is the Asia's international financial centre. Next to Singapore, one may classify Hong Kong as such, being Singapore's main rival, as these two countries are MNC's preferred countries to base their Asian operations (Blair, 1999, Business Asia, 1999, MAS, 2005, Levieux, 2007). The success of Singapore's financial and banking sector, attracting 3600 companies to set up their operations in the country has been a huge success (Monetary Authority of Singapore, 2007), after the small changes suggested by Leow (2005).

Not only are MNCs setting Singapore as a base for their Asian operations: RTCs are establishing themselves there privately, if not on behalf of these MNCs. This brought in treasury activities worth USD 204 billion into Singapore's treasury market in 2004 (Monetary Authority of Singapore, 2007). Singapore and Hong Kong would, therefore, be suitable for the comparative analysis. 
Management, Vol. 14, 2009, 1, pp. 77-101

P. Polak, R. R. Roslan: Regional treasury centres in South East Asia - The case of Brunei...

\subsection{Treasury performance and similar comparative studies}

Brunei's strategic location is excellent to host RTCs. Having a currency exchange on par with Singapore, as well as a fairly high standard of living, the Brunei dollar is quite strong. Monetary policy has been determined by linking the Brunei Darussalam's dollar to the Singapore Dollar and there is parity between the two. The Singapore link is seen as a stabilizing influence. TCs deal a lot with transferring of funds (Potty et al., 2004) and the lack of foreign currency control in Brunei makes it a good location for RTCs in the sense that an important LCn (Location Criterion) that Brunei already posses. However, Brunei is not attracting RTCs, so it probably lacks certain other important LC, which are necessary for RTCs to operate better than in another location. Watanabe (1998) has performed a similar comparative study (to two successful rivals) and concluded that, compared to Singapore and Hong Kong, Taiwan's tax system was outdated and inadequate (Watanabe, 1998). However, instead of focusing on tax, this study focuses on treasury related factors, which includes the tax related issues.

This study has the main core objective of comparatively analyzing Brunei Darussalam's LC and treasury performance to that of Singapore and Hong Kong. Much of the work done on locating RTCs in Asia and Pacific has pointed to Singapore and Hong Kong, followed by Malaysia and Australia (Blair, 1999). Brunei Darussalam already has the important tax LCn at hand of hosting RTCs, but this potential has still been ignored. Zilva (2004) studied Australia's regional operating headquarter taxation incentives by comparing them to Singapore, Malaysia and Thailand. Zilva (2004) and Watanabe (1998) have similar study methods i.e. tax related comparative study. Zilva found that Australia's tax rates are the highest among the four countries investigated and suggested that "the Australian tax laws made Australia comparatively unattractive country to hold foreign investment" (Zilva, 2004, p. 56). Zilva's focus was on the comparative study of regional operating headquarters and the tax concessions offered by four countries; Australia, Singapore, Thailand and Malaysia, while this study will focus on RTCs and the LC offered by Brunei, Singapore and Hong Kong.

\subsection{Objective of the paper}

Recommendations regarding changes that need to be implemented in Brunei, in order to follow the success of other countries (Singapore and Hong Kong) in attracting MNCs to set up RTCs in their region will be made. These 
changes will be in the form of financial and banking (prices for banking services) reforms, as suggested by Simkova (2005, cited in Polak et al. 2007) and other authors. Already being strategically located, Brunei is also politically and economically stable, which includes comprehensive and up-to-date legislation, strong regulatory and supervisory frameworks, low costs for business operation, presence of liquidity, time zone convergence, advanced physical infrastructures, diverse domestic support service, excellent international education and health facilities, and well-educated labor force (Oxford Business Group 2007). By further refining the financial and banking regulations, in competition to international financial centres, such as Singapore and Hong Kong, could make Brunei the next leading location for Regional Treasury Centres.

\section{LOCATION CRITERIA}

The criteria Simkova (2005, cited in Polak et al. 2007) assessed for a holding company (CGS) in Czech Republic are based on cash pooling on a national basis in three currencies, three banks and three structures (Polak et al., 2007). Simkova set the target of locating the ITC for CGS in a country that provides the best conditions for cash flow controlling and administration and which also provides tax advantage. The criteria mentioned previously (the LC), will serve as a set of framework for data collection for the three countries; Brunei Darussalam, Singapore and Hong Kong in this present study and will be compared to identify differences and similarities (if available).

A description of criteria is available in Polak et al. (2007). The academic audience was informed about the location criteria, weighting of criteria, matrix of weighted utility, etc. at a lecture of Petr Polak at the University of Groningen, The Netherlands, in October 2008.

The research methodology is based on a comparison of 11 location criteria (LC) across three countries: Brunei, Hong Kong, and Singapore. The 11 criteria are as follows: (LCn 1) Monthly banking fees, (LCn 2) Bank transaction fees, (LCn 3) Price of incoming foreign payment, (LCn 4) Price of outgoing foreign payment, (LCn 5) Price of foreign urgent payments, (LCn 6) Withholding tax, (LCn 7) Corporate tax, (LCn 8) Important treasury centres, (LCn 9) reporting requirements, ( $\mathrm{LCn} 10$ ) Currency environment, and ( $\mathrm{LCn} 11$ ) Ratings. A summary description of each location criterion (LCn) is provided in Table 1. 
Management, Vol. 14, 2009, 1, pp. 77-101

P. Polak, R. R. Roslan: Regional treasury centres in South East Asia - The case of Brunei...

Table 1. Description of the 11 Location Criteria

\begin{tabular}{|c|c|}
\hline Location Criterion (LCn) & Description \\
\hline 1. Monthly banking fees & $\begin{array}{l}\text { Business account minimum monthly maintenance fees } \\
\text { charged by banks. }\end{array}$ \\
\hline 2. Bank transaction fees & $\begin{array}{l}\text { Minimum fee per transaction charged by banks for } \\
\text { business accounts. }\end{array}$ \\
\hline $\begin{array}{l}\text { 3. Price of incoming foreign } \\
\text { payment }\end{array}$ & $\begin{array}{l}\text { Inward remittance fees }- \text { minimum charge for fund } \\
\text { transferred (buying foreign currency) by foreigners to } \\
\text { their country of residence. }\end{array}$ \\
\hline $\begin{array}{l}\text { 4. Price of outgoing foreign } \\
\text { payment }\end{array}$ & $\begin{array}{l}\text { Outward remittance fees - minimum charge for fund } \\
\text { transferred (selling foreign currency) by foreigners to their } \\
\text { country of residence. }\end{array}$ \\
\hline $\begin{array}{l}\text { 5. Price of outgoing urgent } \\
\text { payment }\end{array}$ & $\begin{array}{l}\text { This service fee is similar for making outgoing payments } \\
\text { but more expensive (minimum charge). }\end{array}$ \\
\hline 6. Withholding tax & $\begin{array}{l}\text { Percentage of payment payers made to residents or non- } \\
\text { residents that are withheld for the local tax authority. }\end{array}$ \\
\hline 7. Corporate tax & $\begin{array}{l}\text { Tax imposed on profits made by companies by local } \\
\text { authority. }\end{array}$ \\
\hline 8. Important treasury centres & $\begin{array}{l}\text { The existence of RTCs in Brunei, Singapore or Hong } \\
\text { Kong. }\end{array}$ \\
\hline 9. Reporting requirements & $\begin{array}{l}\text { Amount of transactions that require to be reported to the } \\
\text { central bank or monetary authority. }\end{array}$ \\
\hline 10. Currency environment & $\begin{array}{l}\text { Possibility of financial transactions in another currency, } \\
\text { especially Euros, US dollars, and Pounds; convertibility of } \\
\text { a domestic currency. Foreign currency accounts and } \\
\text { services. }\end{array}$ \\
\hline 11. Ratings & $\begin{array}{l}\text { Credit ratings by rating company Coface given to Brunei, } \\
\text { Singapore and Hong Kong. Rating A1 ("best") to rating D } \\
\text { ("worst") (Coface launches a new "business climate" } \\
\text { rating). }\end{array}$ \\
\hline
\end{tabular}

The data collection process involved gathering information on each of the 11 criteria from secondary data sources, with data collection and analysis methods varying, depending on the criterion (see below) but conducted simultaneously. 
Much of the data (mostly pricing for services provided by banks for businesses/corporations) were sourced from the top three leading banks in each country, measured by asset size: Hong Kong (HSBC, Bank of China and Hang Seng Bank), Singapore (DBS Bank, United Overseas Bank and OCBC Bank), except for Brunei, as the data from this country is not as readily available.

The three banks for the case of Brunei are selected according to the latest ranking of the Asian banks (Asian Bank Rankings 2004) from FinanceAsia magazine referred at the Internet (http://asianbanks.net). According to this raking, out of the eight banks in Brunei, HSBC has the largest asset size, followed by United Overseas Bank and the Malayan Bank (Maybank). Other sources of data include academic database and treasury websites for recent articles, central bank websites and Asia's Treasurer Handbook 2008 for tax related criterion.

Data for seven of the LC (LC 1, 2, 3, 4, 5, 6, and 7) are quantitative, as these criteria are based on tax percentages, minimum average fees and prices for bank services. Data for the remaining four LC (criteria 8, 9, 10 and 11) are qualitative: mostly descriptive information gathered predominantly from online sources. The data collection procedure for each criterion in each country is described in more detail below. A comparative analysis of the $11 \mathrm{LC}$ across the three countries, identifying similarities and differences, is presented in the section dealing with the research results.

The study employed a deductive approach, as suggested by Saunders (2007). According to the Simkova (2005, cited in Polak et al. 2007), there are 11 criteria that needs to be examined (the $11 \mathrm{LC}$ ) to assess the condition of a location to determine its suitability to host RTCs. Therefore, the objective of the current study was to compare these $11 \mathrm{LC}$ across three countries: Brunei versus Hong Kong and Singapore.

\section{DATA COLLECTION PROCEDURE}

A summary of the data sources used for each criterion across the three countries is provided in Table 2 . 
Management, Vol. 14, 2009, 1, pp. 77-101

P. Polak, R. R. Roslan: Regional treasury centres in South East Asia - The case of Brunei...

Table 2. Summary of the data sources used for each criterion in Brunei Darussalam, Hong Kong, and Singapore

\begin{tabular}{|c|c|c|c|c|c|}
\hline \multirow{2}{*}{ 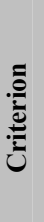 } & $\begin{array}{l}\text { Bank } \\
\text { transaction fees }\end{array}$ & Corporate tax & $\begin{array}{c}\text { Currency } \\
\text { environment }\end{array}$ & $\begin{array}{c}\text { Important } \\
\text { treasury } \\
\text { centres } \\
\end{array}$ & $\begin{array}{l}\text { Monthly bank } \\
\text { fees }\end{array}$ \\
\hline & $\begin{array}{l}\text { Price for foreign } \\
\text { incoming } \\
\text { payments }\end{array}$ & $\begin{array}{l}\text { Price for foreign } \\
\text { outgoing } \\
\text { payments }\end{array}$ & $\begin{array}{l}\text { Price for urgent } \\
\text { outgoing foreign } \\
\text { payments }\end{array}$ & Ratings & $\begin{array}{c}\text { Reporting } \\
\text { requirements }\end{array}$ \\
\hline \multirow{2}{*}{ 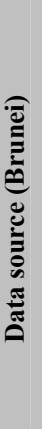 } & $\begin{array}{l}\text { Calculating the } \\
\text { average minimum } \\
\text { charge of top } 3 \\
\text { banks (by asset } \\
\text { size) }\end{array}$ & $\begin{array}{l}\text { Brunei Economic } \\
\text { Development } \\
\text { Board }\end{array}$ & $\begin{array}{l}\text { Banks (HSBC, } \\
\text { UOB \& Maybank) }\end{array}$ & $\begin{array}{l}\text { Search of } \\
\text { recent } \\
\text { articles from } \\
\text { academic } \\
\text { databases } \\
\text { and WWW }\end{array}$ & $\begin{array}{l}\text { Calculating the } \\
\text { average minimum } \\
\text { charge of top } 3 \\
\text { banks (by asset } \\
\text { size) }\end{array}$ \\
\hline & $\begin{array}{l}\text { Calculating the } \\
\text { average minimum } \\
\text { charge of top } 3 \\
\text { banks (by asset } \\
\text { size) }\end{array}$ & $\begin{array}{l}\text { Calculating the } \\
\text { average } \\
\text { minimum charge } \\
\text { of top } 3 \text { banks } \\
\text { (by asset size) }\end{array}$ & $\begin{array}{l}\text { Calculating the } \\
\text { average minimum } \\
\text { charge of top } 3 \\
\text { banks (by asset } \\
\text { size) }\end{array}$ & $\begin{array}{l}\text { Ratings } \\
\text { website - } \\
\text { trading- } \\
\text { safely.com }\end{array}$ & $\begin{array}{l}\text { From Monetary } \\
\text { Authority/Central } \\
\text { bank website - } \\
\text { Ministry of } \\
\text { Finance }\end{array}$ \\
\hline \multirow{2}{*}{ 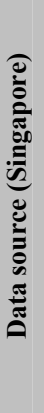 } & $\begin{array}{l}\text { Calculating the } \\
\text { average minimum } \\
\text { charge of top } 3 \\
\text { banks (by asset } \\
\text { size) }\end{array}$ & $\begin{array}{l}\text { Asia Treasurer's } \\
\text { Handbook } 2008\end{array}$ & $\begin{array}{l}\text { Banks (DBS, } \\
\text { United Overseas \& } \\
\text { OCBC) }\end{array}$ & $\begin{array}{l}\text { Search of } \\
\text { recent } \\
\text { articles from } \\
\text { academic } \\
\text { databases } \\
\text { and WWW }\end{array}$ & $\begin{array}{l}\text { Calculating the } \\
\text { average minimum } \\
\text { charge of top } 3 \\
\text { banks (by asset } \\
\text { size) }\end{array}$ \\
\hline & $\begin{array}{l}\text { Calculating the } \\
\text { average minimum } \\
\text { charge of top } 3 \\
\text { banks (by asset } \\
\text { size) }\end{array}$ & $\begin{array}{l}\text { Calculating the } \\
\text { average } \\
\text { minimum charge } \\
\text { of top } 3 \text { banks } \\
\text { (by asset size) }\end{array}$ & $\begin{array}{l}\text { Calculating the } \\
\text { average minimum } \\
\text { charge of top } 3 \\
\text { banks (by asset } \\
\text { size) }\end{array}$ & $\begin{array}{l}\text { Ratings } \\
\text { website- } \\
\text { trading- } \\
\text { safely.com }\end{array}$ & $\begin{array}{l}\text { From Monetary } \\
\text { Authority/Central } \\
\text { bank website - } \\
\text { Monetary } \\
\text { Authority of } \\
\text { Singapore }\end{array}$ \\
\hline \multirow{2}{*}{ 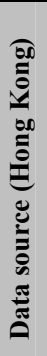 } & $\begin{array}{l}\text { Calculating the } \\
\text { average minimum } \\
\text { charge of top } 3 \\
\text { banks (by asset } \\
\text { size) }\end{array}$ & $\begin{array}{l}\text { Asia Treasurer's } \\
\text { Handbook } 2008\end{array}$ & $\begin{array}{l}\text { Banks (HSBC, } \\
\text { Bank of China \& } \\
\text { Hang Seng Bank) }\end{array}$ & $\begin{array}{l}\text { Search of } \\
\text { recent } \\
\text { articles from } \\
\text { academic } \\
\text { databases } \\
\text { and WWW } \\
\end{array}$ & $\begin{array}{l}\text { Calculating the } \\
\text { average minimum } \\
\text { charge of top } 3 \\
\text { banks (by asset } \\
\text { size) }\end{array}$ \\
\hline & $\begin{array}{l}\text { Calculating the } \\
\text { average minimum } \\
\text { charge of top } 3 \\
\text { banks (by asset } \\
\text { size) }\end{array}$ & $\begin{array}{l}\text { Calculating the } \\
\text { average } \\
\text { minimum charge } \\
\text { of top } 3 \text { banks } \\
\text { (by asset size) }\end{array}$ & $\begin{array}{l}\text { Calculating the } \\
\text { average minimum } \\
\text { charge of top } 3 \\
\text { banks (by asset } \\
\text { size) }\end{array}$ & $\begin{array}{l}\text { Ratings } \\
\text { website - } \\
\text { trading- } \\
\text { safely.com }\end{array}$ & $\begin{array}{l}\text { From Monetary } \\
\text { Authority/Central } \\
\text { bank website - } \\
\text { Ministry of } \\
\text { Finance }\end{array}$ \\
\hline
\end{tabular}




\section{COMPARATIVE ANALYSIS}

Data collected were simplified into appropriate tables for clear comparisons for the three different countries. Each LCn was analyzed separately, in order to clearly spot differences or similarities across the three countries. LC with quantitative data (LCn 1 to LCn 7) related to prices and tax percentages are grouped and measured in terms of the most (un)favorable. The country with higher figures for each LCn will offer more expensive condition for RTC to operate. LCn 8 to LCn 11, i.e. LC measured by qualitative data are compared across the three countries as well.

\subsection{Conversion to the Australian dollars}

All averaged minimum prices for services provided by banks from each country were converted to Australian Dollars (AUD), according to Westpac $2^{\text {nd }}$ October 2008 monthly average exchange rates (Westpac Monthly average exchange rates 2008) to simplify the procedure of comparing the costs of services the banks provide. The bank fees were originally quoted in different currencies i.e. Brunei Dollars (BND), Singapore Dollars (SGD) and Hong Kong Dollars (HKD).

The results are based on available data collected for every LCn in each of three countries, by using the previously described data collection procedure and on the comparative analysis of the data. The results for establishing whether Brunei has the facilities to accommodate RTCs, similar to Singapore and Hong Kong, is based on the comparison of LC for the three countries.

\section{COMPARATIVE ANALYSIS AND RESULTS}

Table 3 assesses the LCn 1, i.e. monthly banking fees, compared across the three countries (Brunei, Singapore and Hong Kong). After converting the three different currencies to AUD, according to the Westpac Bank currency exchange rate, it can be concluded that Hong Kong offers the lowest average fees for maintaining a business account (at the rate of AUD 5.75), while Brunei offers the highest average monthly fees. 
Management, Vol. 14, 2009, 1, pp. 77-101

P. Polak, R. R. Roslan: Regional treasury centres in South East Asia - The case of Brunei...

Table 3. Monthly bank fees

\begin{tabular}{|l|c|c|c|}
\hline Location Criterion (1) & Brunei & Singapore & Hong Kong \\
\hline Monthly bank fees & BND20.67 & SGD15 & HKD36.67 \\
\hline Exchange rate (AUD1) & 1.1697 & 1.1697 & 6.3725 \\
\hline Monthly bank fees (AUD) & 17.67 & 12.82 & 5.75 \\
\hline
\end{tabular}

Table 4 presents the average banking transaction fees (cost per transaction) compared across the three countries. Singapore offers the lowest average banking transaction fee of AUD 0.28, compared to Brunei (AUD 7.12) and Hong Kong (AUD 8.90).

Table 4. Bank transaction fees

\begin{tabular}{|l|c|c|c|}
\hline Location Criterion (2) & Brunei & Singapore & Hong Kong \\
\hline Bank transaction fees & BND8.33 & SGD0.33 & HKD56.67 \\
\hline Exchange rate (AUD1) & 1.1697 & 1.1697 & 6.3725 \\
\hline Bank transaction fees (AUD) & 7.12 & 0.28 & 8.90 \\
\hline
\end{tabular}

Hong Kong offers the lowest average price for the incoming foreign payment banking service of AUD 6.54, compared to the average foreign incoming prices calculated for Brunei (AUD 12.85) and Hong Kong (AUD $6.54)$.

Table 5. Price of foreign incoming payment

\begin{tabular}{|l|c|c|c|}
\hline Location Criterion (3) & Brunei & Singapore & Hong Kong \\
\hline $\begin{array}{l}\text { Price for foreign incoming } \\
\text { payment }\end{array}$ & BND15.03 & SGD10 & HKD41.67 \\
\hline Exchange rate (AUD1) & 1.1697 & 1.1697 & 6.3725 \\
\hline $\begin{array}{l}\text { Price for foreign incoming } \\
\text { payment (AUD) }\end{array}$ & 12.85 & 8.55 & 6.54 \\
\hline
\end{tabular}

Table 6 assesses the LCn 4, i.e. the average price of banking service for making foreign outgoing payment, compared across the three countries. Brunei offers the highest average fee for this LCn of AUD 21.37, while Singapore offers the lowest averaged fee for making foreign outgoing payment of AUD 12.82 . 
Table 6. Price for foreign outgoing payment

\begin{tabular}{|l|c|c|c|}
\hline Location Criterion (4) & Brunei & Singapore & Hong Kong \\
\hline $\begin{array}{l}\text { Price for foreign outgoing } \\
\text { payment }\end{array}$ & BND25 & SGD15 & HKD116.67 \\
\hline Exchange rate (AUD1) & 1.1697 & 1.1697 & 6.3725 \\
\hline $\begin{array}{l}\text { Price for foreign outgoing } \\
\text { payment (AUD) }\end{array}$ & 21.37 & 12.82 & 18.31 \\
\hline
\end{tabular}

Table 7 appraises LCn 5, i.e. the price for making urgent foreign outgoing payments. The average price compared across the three countries shows Brunei offers the most expensive services at the average rate of AUD 21.40, while Singapore offers the lowest average rate of AUD 12.82.

Table 7. Price of urgent foreign payments

\begin{tabular}{|l|c|c|c|}
\hline Location Criterion (5) & Brunei & Singapore & Hong Kong \\
\hline Urgent foreign payments price & BND25.03 & SGD15 & HKD156.67 \\
\hline Exchange rate (AUD1) & 1.1697 & 1.1697 & 6.3725 \\
\hline $\begin{array}{l}\text { Urgent foreign payments price } \\
\text { (AUD) }\end{array}$ & 21.40 & 12.82 & 24.59 \\
\hline
\end{tabular}

Table 8 assesses LCn 6 (withholding tax). The withholding tax of all three countries were collected and compared. Singapore offers the lowest, when compared to Brunei, but Hong Kong does not impose withholding tax. However, in certain circumstances, $1.75 \%$ of royalties is subjected to tax.

Table 8. Withholding tax

\begin{tabular}{|l|c|c|c|}
\hline Location Criterion (6) & Brunei & Singapore & Hong Kong \\
\hline Withholding tax & $20 \%$ & $15 \%$ & N/A \\
\hline
\end{tabular}

Table 9 shows corporate tax ( $\mathrm{LCn} 7$ ) compared across the three countries. Brunei has corporate tax of $30 \%$, Singapore $18 \%$ and Hong Kong the lowest one (17.5\%). 
Management, Vol. 14, 2009, 1, pp. 77-101

P. Polak, R. R. Roslan: Regional treasury centres in South East Asia - The case of Brunei...

Table 9. Corporate tax

\begin{tabular}{|l|c|c|c|}
\hline Location Criterion (7) & Brunei & Singapore & Hong Kong \\
\hline Corporate tax & $30 \%$ & $18 \%$ & $17.5 \%$ \\
\hline
\end{tabular}

Table 10 presents the existing important treasury centres that have already been located in each of the three countries, which represents the presents LCn 8 . There are no RTCs in Brunei, quite a few in Singapore (including those of multinationals, such as Nokia, Sony, UPS, Caltex, Ericsson, etc.), as well as a few in Hong Kong, as well (including JP Morgan and P \& O Nedlloyd's).

Table 10. Important treasury centres

\begin{tabular}{|l|c|c|c|}
\hline Location Criterion (8) & Brunei & Singapore & Hong Kong \\
\hline Important treasury centres & none & $\begin{array}{c}\text { Nokia, Nissan, } \\
\text { Sony, UPS, } \\
\text { Caltex etc }\end{array}$ & $\begin{array}{c}\text { JP Morgan, P\&O } \\
\text { Nedlloyd's }\end{array}$ \\
\hline
\end{tabular}

Table 11 presents results related to LCn 9 (reporting requirements to central banks/Monetary Authority for banking transactions). Brunei and Singapore offer minimum reporting requirements to the Monetary Authority, while Hong Kong requires gross amount of lending and borrowing reporting (Hong Kong Monetary Authority 2005).

Table 11. Reporting requirements

\begin{tabular}{|l|c|c|c|}
\hline Location Criterion (9) & Brunei & Singapore & Hong Kong \\
\hline Reporting requirements & $\begin{array}{c}\text { Only certain } \\
\text { threshold. }\end{array}$ & $\begin{array}{c}\text { No capital } \\
\text { controls }\end{array}$ & Some control \\
\hline
\end{tabular}

Table 12 assesses the currency environment of each country (LCn 10), in terms of the ability of MNCs to make transactions in major foreign currencies, such as USD, EUR, GBP, AUD, etc. Most banks in the three countries offer banking facilities in the mentioned foreign currencies.

Table 12. Currency environment

\begin{tabular}{|l|c|c|c|}
\hline Location Criterion (10) & Brunei & Singapore & Hong Kong \\
\hline \multirow{3}{*}{ Currency environment } & USD, EUR, & USD, EURO, & USD, EURO, \\
& GBP, AUD, & AUD, GBP, & AUD, GBP, \\
& JPY etc & JPY etc & JPY etc \\
\hline
\end{tabular}


Management, Vol. 14, 2009, 1, pp. 77-101

P. Polak, R. R. Roslan: Regional treasury centres in South East Asia - The case of Brunei...

Table 13 shows the credit ratings of three countries. Both Singapore and Hong Kong hold the A1 business climate and country credit ratings.

Table 13. Ratings

\begin{tabular}{|l|c|c|c|}
\hline Location Criterion (11) & Brunei & Singapore & Hong Kong \\
\hline Ratings & N/A & A1 & A1 \\
\hline
\end{tabular}

The following table summarizes analysis of all the previous location criteria.

Table 14. Summary of results (monetary values in Australian dollars - AUD)

\begin{tabular}{|l|l|c|c|c|}
\hline No. & $\begin{array}{l}\text { Location Criterion } \\
\text { (LCn) }\end{array}$ & Brunei & Singapore & Hong Kong \\
\hline $\mathbf{1}$ & Monthly bank fees & 17.67 & 12.82 & 5.75 \\
\hline $\mathbf{2}$ & Bank transaction fees & 7.12 & 0.28 & 8.90 \\
\hline $\mathbf{3}$ & $\begin{array}{l}\text { Price for foreign } \\
\text { incoming payment }\end{array}$ & 12.85 & 8.55 & 6.54 \\
\hline $\mathbf{4}$ & $\begin{array}{l}\text { Price for foreign } \\
\text { outgoing payment }\end{array}$ & 21.37 & 12.82 & 18.31 \\
\hline $\mathbf{5}$ & $\begin{array}{l}\text { Urgent foreign payments } \\
\text { fees }\end{array}$ & 21.40 & 12.82 & 24.59 \\
\hline $\mathbf{6}$ & Withholding tax & $20 \%$ & $15 \%$ & N/A \\
\hline $\mathbf{7}$ & Corporate tax & $30 \%$ & $18 \%$ & $18 \%$ \\
\hline $\mathbf{8}$ & $\begin{array}{l}\text { Important treasury } \\
\text { centres }\end{array}$ & None & Several & Several \\
\hline $\mathbf{9}$ & Reporting requirements & Minimum & Minimum & Minimum \\
\hline $\mathbf{1 0}$ & Currency environment & $\begin{array}{c}\text { GSD, EURO, AUD, JPY } \\
\text { etc }\end{array}$ & $\begin{array}{c}\text { USD, EURO, GBP, JPY } \\
\text { etc }\end{array}$ & $\begin{array}{c}\text { USD, EURO, GBP, JPY } \\
\text { AUD }\end{array}$ \\
\hline $\mathbf{1 1}$ & Ratings & N/A & A1 & A1 \\
\hline
\end{tabular}

\section{DISCUSSION OF QUALITATIVE AND QUANTITATIVE LC}

This paper examines whether Brunei Darussalam has the opportunities and/or resources to become the next leading location for RTCs in Asia. By using a similar method of finding suitable location for a RTC - Simkova (2005, cited in Polak et al. 2007), this study produces results similar to Simkova (2005). The main functions of treasury management, i.e. cash management (Mulligan, 2001), especially making foreign payments, which are in the focus of the study performed by Simkova (2005), are also analyzed in this paper. 
Discussion of each result of LC found is focused on whether Brunei can compete with the other two countries, which are currently the leading locations for RTCs. Results of LC with quantitative data (LCn $1-\mathrm{LCn} 7)$ are discussed first, followed by the analysis of criteria LCn 8 to LCn 11 (based on qualitative data).

Table 15. Assessment of quantitative LC

\begin{tabular}{|l|l|c|c|c|}
\hline No. & $\begin{array}{l}\text { Location Criterion } \\
\text { (LCn) }\end{array}$ & Brunei & Singapore & Hong Kong \\
\hline $\mathbf{1}$ & Monthly bank fees & Highest & Middle & Lowest \\
\hline $\mathbf{2}$ & Bank transaction fees & Middle & Lowest & Highest \\
\hline $\mathbf{3}$ & $\begin{array}{l}\text { Price for foreign } \\
\text { incoming payment }\end{array}$ & Highest & Middle & Lowest \\
\hline $\mathbf{4}$ & $\begin{array}{l}\text { Price for foreign } \\
\text { outgoing payment }\end{array}$ & Highest & Lowest & Middle \\
\hline $\mathbf{5}$ & $\begin{array}{l}\text { Urgent foreign payments } \\
\text { price }\end{array}$ & Middle & Lowest & Highest \\
\hline $\mathbf{6}$ & Withholding tax & Highest & Middle & Lowest \\
\hline $\mathbf{7}$ & Corporate tax & Highest & Middle & Lowest \\
\hline $\mathbf{8}$ & $\begin{array}{l}\text { Important treasury } \\
\text { centres }\end{array}$ & None & Existing RTCs & Existing RTCs \\
\hline $\mathbf{9}$ & Reporting requirements & Minimal & Minimal & Minimal \\
\hline $\mathbf{1 0}$ & Currency environment & 1 bank & 3 banks & 3 banks \\
\hline $\mathbf{1 1}$ & Ratings & N/A & Best & Best \\
\hline
\end{tabular}

Notes: Highest - LCn with the highest figure, Middle - LCn with not the highest or the lowest figure, Lowest - LCn with the lowest figure.

\subsection{Discussion of quantitative data results $(\operatorname{LCn} 1-\operatorname{LCn} 7)$}

Table 16 represents assessment of the three countries, regarding the unfavorable $\mathrm{LC}$ values. For $\mathrm{LCn} 1-\mathrm{LCn} 7$, the target is to minimize the high figures for each country. In order to assess competitiveness of Brunei's current condition for hosting RTC, it is easily demonstrated that the country currently holds $71.4 \%$ of the unfavorable ranks significant for a suitable location of a RTC. Hong Kong has $28.6 \%$ of such LC ranks, while Singapore has none. 
Management, Vol. 14, 2009, 1, pp. 77-101

P. Polak, R. R. Roslan: Regional treasury centres in South East Asia - The case of Brunei...

Table 16. Countries with unfavourable LC values

\begin{tabular}{|l|l|l|l|c|}
\hline No. & Location Criterion (LC) & Brunei & Singapore & Hong Kong \\
\hline $\mathbf{1}$ & Monthly bank fees & Highest & & \\
\hline $\mathbf{2}$ & Bank transaction fees & & & Highest \\
\hline $\mathbf{3}$ & $\begin{array}{l}\text { Price for foreign } \\
\text { incoming payment }\end{array}$ & Highest & & \\
\hline $\mathbf{4}$ & $\begin{array}{l}\text { Price for foreign } \\
\text { outgoing payment }\end{array}$ & Highest & & Highest \\
\hline $\mathbf{5}$ & $\begin{array}{l}\text { Urgent foreign payments } \\
\text { price }\end{array}$ & & & \\
\hline $\mathbf{6}$ & Withholding tax & Highest & & \\
\hline $\mathbf{7}$ & Corporate tax & Highest & & \\
\hline
\end{tabular}

It can be concluded that Brunei offers the most expensive banking service related to RTC functions and higher percentage tax for MNCs, compared to the banks in Singapore and Hong Kong.

Hong Kong and Singapore have $57.1 \%$ and $48.9 \%$ of the most favorable quantitative LC ranks (respectively), while Brunei has none (see Table 17). Singapore and Hong Kong have the lowest average fees for banking service and low percentage tax. At the other hand, Brunei neither offers the affordable banking service, nor the tax rate suitable for RTCs.

Table 17. Countries with favourable LC values

\begin{tabular}{|l|l|l|c|c|}
\hline No. & Location Criterion (LC) & Brunei & Singapore & Hong Kong \\
\hline $\mathbf{1}$ & Monthly bank fees & & & Lowest \\
\hline $\mathbf{2}$ & Bank transaction fees & & Lowest & Lowest \\
\hline $\mathbf{3}$ & $\begin{array}{l}\text { Price for foreign } \\
\text { incoming payment }\end{array}$ & & & \\
\hline $\mathbf{4}$ & $\begin{array}{l}\text { Price for foreign } \\
\text { outgoing payment }\end{array}$ & & Lowest & \\
\hline $\mathbf{5}$ & $\begin{array}{l}\text { Urgent foreign payments } \\
\text { price }\end{array}$ & & Lowest & \\
\hline $\mathbf{6}$ & Withholding tax & & & Lowest \\
\hline 7 & Corporate tax & & & Lowest \\
\hline
\end{tabular}


Management, Vol. 14, 2009, 1, pp. 77-101

P. Polak, R. R. Roslan: Regional treasury centres in South East Asia - The case of Brunei...

\subsection{Discussion of qualitative data results $(\operatorname{LCn} 8-\operatorname{LCn} 11)$}

\section{LCn 8 - Important treasury centres}

Table 18 shows the assessment for qualitative LC. For LCn 8, Brunei can not be rated, as there are no RTCs present, compared to those that have been set up in Singapore and Hong Kong. There are currently about 150 RTC operations in Singapore, according to recent study by PricewaterhouseCoopers (Giumarra 2001), which is the largest number of RTCs in Asia Pacific (Kini, 2007). With already existing RTCs, Singapore and Hong Kong both are in an already good position for future RTCs to be located there by prospective MNCs. The availability of other RTCs in the region would show that the region already has the treasury function support needed by this entity.

Table 18. Assessment of quantitative LC

\begin{tabular}{|l|l|c|c|c|}
\hline No. & $\begin{array}{l}\text { Location Criterion } \\
\text { (LCn) }\end{array}$ & Brunei & Singapore & Hong Kong \\
\hline $\mathbf{8}$ & $\begin{array}{l}\text { Important treasury } \\
\text { centres }\end{array}$ & Zero & One & One \\
\hline $\mathbf{9}$ & Reporting requirements & Minimum & Minimum & Minimum \\
\hline $\mathbf{1 0}$ & Currency environment & 1 bank & 3 banks & 3 banks \\
\hline $\mathbf{1 1}$ & Ratings & None & Best & Best \\
\hline
\end{tabular}

\section{LCn 9 - Reporting requirements}

Out of the three countries assessed for this LC, Hong Kong and Brunei share a fair reporting requirement to the central bank/Monetary Authority. While, in Hong Kong, banks are required to report gross lending and borrowing, any amount of fund transfer reaching a certain threshold would need to be reported to the Ministry of Finance, i.e. Brunei Monetary Authority. According to the data collected, Singapore has the least reporting requirements, which makes it a more favorable destination for RTCs.

\section{LCn 10 - Currency Environment}

Out of the three banks assessed in Brunei, only one offers foreign currency account and services, including important currencies, such as the USD, EURO, GBP, AUD, CAD, JPY and many more. The other two international banks do not provide services with these currencies, while all three banks, from both Singapore and Hong Kong, provide both services in the previously mentioned 
foreign currencies, as well as in many others. The ability to conduct transactions in foreign currencies is a crucial part of a RTC function. As the RTCs deal with cash management, especially with the cross-border transfers, the ability to provide instant conversion of currencies serves well in making a location suitable to accommodate a RTC.

\section{LCn 11 - Ratings}

Ratings offered by Coface consider a country's overall liquidity and solvency (i.e. its "business climate"). Singapore and Hong Kong are both given the best rating of $\mathrm{A} 1$ for their business climate, whereas it is difficult to find online ratings for Brunei.

\section{DISCUSSION AND RECOMMENDATIONS}

\subsection{Discussion}

From the results, it can be clearly concluded that Brunei Darussalam has more expensive banking service fees and charges and higher percentage tax imposed on company profits by the local authority, compared to Singapore and Hong Kong. This may be the first obvious sign indicating Brunei's lower level of competitiveness, not only in terms of attracting RTCs, but also in attracting MNCs. Major companies deal with major movements of funds, in amounts of millions, or even billions. If Brunei falls short in competing with the other countries, they will become the preferred location for regional headquarters or finance offices to be set up by these major companies (Economist Intelligence Unit Limited, 2000). Competing closely to Singapore and Hong Kong, as these two countries are Asia's international financial centres (Levieux, 2007), is important, if Brunei are to follow in their footsteps.

The averaged price for making overseas payments provided by the banks in Brunei is higher than those offered in Singapore and Hong Kong. MNCs originating from other countries will not benefit from cost savings by locating their regional operations in Brunei. Profits will not be taxed as much in Hong Kong or Singapore compared to Brunei, which has the highest corporate tax imposed on profits. Having the highest percentage of withholding tax also reduces Brunei's competitiveness in attracting RTCs, as these entities are primarily tax driven (Anwar 1999, Zink 1995, Murphy 2000a, Casalino 2001, Giegerich et al 2002, Simkova 2005, Polak 2007). A benign tax system is the crucial aspect to attracting RTCs (Mulligan, 2001). 
In terms of existing RTCs in the region, Brunei currently has none. The closest RTC is in Labuan - an island eight kilometer off the coast of Borneo, where Brunei Darussalam is located (Wikipedia, 2008). The RTC is the regional finance office with treasury functions for Shell Malaysia. Due to this, considering Brunei as a prospective location for an RTC may not be viable. At the other hand, Singapore is the fourth largest trader in derivatives and the ninth largest offshore lender, which makes it an attractive location for setting up a RTC, with already approximately 150 existing RTCs (Giumarra, 2001). Hong Kong is the next favorite location for regional headquarters of MNCs and RTCs in Asia (Business Asia, 2000, Levieux, 2007). Although the actual number of RTCs that have been established in Hong Kong is not available, it can be definitely considered as the major rival of Singapore.

Flexible regulation is also a factor to consider when considering a location for a RTC (Zink, 1995, Anwar, 1999, Geigerich, 2002). Although Brunei currently does not strictly regulate transfer of funds between financial institutions, this is also not the casefor Singapore and Hong Kong. The facility for foreign currency transaction is already available in Brunei, although it is not as developed compared to Singapore and Hong Kong. Some banks in Brunei offer accounts and services in most important foreign currencies, i.e. USD, EURO, GBP, AUD, JPY, SGD, and a few more. This shows that Brunei has some potential to start off the improvements needed to improve its position to attract RTCs or even regional headquarters of MNCs.

At the time of writing, Singapore and Hong Kong had the best Coface ratings for the country's business climate. Other than having a good business environment, Singapore and Hong Kong are considered by this rating company to have "available and reliable corporate financial information together with very good institutional quality". Information regarding Brunei should be also easily available to potential overseas investors, which is not the case now.

\subsection{Recommendations}

In order to compete with Singapore and Hong Kong, it is important for Brunei to remain vigilant in terms of regulations significant for potential overseas investors. According to this study, reassessing banking facility charges for businesses/corporations, especially the international ones, would be a fair start. Next, Brunei's current taxation regulations, imposed on any types of companies both local and international, should be examined. Singapore and 
Hong Kong are in a better position in terms of attracting RTCs or regional headquarters of MNCs, as their tax is lower. Nokia chose Singapore over Hong Kong, Malaysia and Australia due to unattractive tax regimes offered by the other three countries (Blair, 1999). Tax reforms will certainly attract foreign investors into Brunei, as Singapore attracted over 3600 regional headquarters in 2003 (up from 49 in 1993) through tax concessions (Zilva, 2004). As local tax regulation is the primary factor when considering location for RTC (Zink, 1995, Anwar, 1999, Casalino, 2001, Geigerich, 2002, Simkova, 2005, Polak, 2007), it should be regulated tax system according to the Singapore and Hong Kong benchmarks.

Increasing the number of students with a major in finance at university level could also benefit Brunei in the long term, as RTCs require trained specialists in the area finance and are ideally located in areas which have experts with treasury related competences (Murphy, 2000a, 2000b, Casalino, 2001, Geigerich, 2002).

\section{CONCLUSION}

There are many more factors to consider when considering a location for RTCs. Simkova (2005, cited in Polak et al., 2007) provides a full description of the specific needs of a holding company in Czech Republic and formulates the LC (utilized in this study) to investigate the conditions of European for the location of this holding company's RTC. This study uses the similar methodology and reaches the conclusion that Brunei does not have the required resources or abilities to efficiently host an RTC, when compared to Singapore and Hong Kong. However, this conclusion is incomplete, because LC utilized in this study are merely one aspect of examining a potential RTC location. It is one of the methods how to assess such a location and there may be additional possible variables, which need to be considered. These include the language barriers, availability of expertise and outsourcing options, access to key financial markets and banking centres, stability of communication networks, time zone, notional pooling, cash concentration and many more (Zink 1995, Anwar, 1999, Murphy 2000a, 2000b, Casalino, 2001, Giegerich, 2002, Simkova, 2005).

All the other potential LC need to be investigated, as well to completely indicate if a location, such as Brunei Darussalam, can successfully host a regional treasury centre. This is the limitation of this study, which remains the future research task. Another limitation is related to establishing the fact (either 
statistically, or mathematically) that more favorable LC (for example, that of Singapore and Hong Kong) do result in attraction of RTCs and improvement of their operations in terms of cost efficiencies (minimal banking costs and low tax), minimal restrictions for fund transfers between the entities involved (banks, RTCs and companies).

\section{REFERENCES}

1. Anwar, T., 1999, Conducting a Feasibility Study for a Regional Centre (RTC), GTnews: The treasury \& finance network, viewed 23 June 2008, http://www.gtnews.com/article/1146.cfm.

2. Asianbanks.net, 2004, Asian Bank Rankings, AsianBanks.net, viewed 16 July 2008, http://asianbanks.net/HTML/Rankings/rank-asia.htm.

3. Blair, N., 1999, "Corporate Treasury in Singapore", The Treasurer, viewed 26 March 2008, http://www.gtnews.com/article/1420.cfm

4. Casalino, M., 2001, "Europe: Sitting a Treasury Center", GTnews: The treasury and finance network, viewed 1 April 2008, http://www.gtnews.com/article/3674.cfm

5. Central Intelligence Agency, 2008, "Brunei", The World Fact Book, viewed 22 March 2008, https://www.cia.gov/library/publications/the-worldfactbook/geos/bx.html.

6. Chang, R. W., (not dated), The UPS model for a Shared Service Centre, Treasury Management International, viewed 19 July 2008, http://www.treasury-management.com/showarticle.php?article=669\&pubid $=4 \&$ issueid $=73$

7. Coface, (not dated), Coface launches a new business climate rating, viewed 4 July 2008, http://www.swinburne.edu.au/lib/researchhelp/harvard system.htm.

8. De Zilva, A., 2004, Tax Concessions for Regional Operating Headquarter Companies: A Comparative Study of Singapore, Malaysia, Thailand and Australia, Australian Journal of Asian law, Vol. 6, Issue 1, viewed 3 June 2008, http://search.informit.com.au/documentSummary; $\mathrm{dn}=5806400575611$ 94;res=E-LIBRARY.

9. Giegerich, U., Lissis, A., 2002, "Implementing a Treasury Center in Switzerland", GT news: The treasury and finance network, viewed1 April 2008, http://www.gtnews.com/article/4536.cfm

10. Giumarra, R., 2001, Cash Management in Singapore, Gtnews.com: the treasury \& finance network, viewed 25 April 2008, http://www.gtnews.com/article/2865.cfm 
11. Horton, A. V. M, 2004, Window-Dressing an Islamizing Sultanate. Asian Survey, Volume 45, Number 1 (January/February 2005), pp. 180-185

12. Kini, M 2007, Cash Management in Singapore, GTnews.com: the treasury \& finance network, viewed 23 May 2008, http://www.gtnews.com/ article/6831.cfm

13. Leow, E, 2005, "Singapore's 2005 Budget: Tax Implications for MultiNationals Companies, Intertax, Vol. 33, Issue 6/7, pp. 301-302

14. Levieux, S., 2007, "Where Should You Locate You Regional Treasury Centre?" HSBC's Guide to Cash and Treasury Management in Asia Pacific 2007, pp. 50-54, viewed 27 March 2008, http://www.hsbcnet.com/ transaction/attachments/APH/pdf/03_cmp_where.pdf

15. Mulligan, E., 2001, "Treasury Management Organisation: An examination of Centralised versus Decentralised Approaches", Irish Journal of Management, Vol. 22, Issue 1

16. Murphy, A., 2000(a), "Solving the problems of globalization", Treasury Management International, pp. 49-54, viewed 1 April 2008, http://www.fti.ie/documents/Solving\%20the $\% 20$ problems\%20of\%20Global isation.pdf

17. Murphy, A., 2000(b), "Non-tax factors in treasury centre decisions", The Treasurer, pp. 56-58, viewed 2 April 2008, http://www.treasurers.org /purchase/customcf/download.cfm?resid=519

18. Polak, P., Kocurek, K., 2007, "Dulcius Ex Asperis - How cash pooling works in the Czech Republic", Management, Vol. 12, No. 2, pp. 85-95. Viewed 18 March 2008, http://www.efst.hr/management/Vol12No22007/6-polak-kocurek.doc

19. Potty, B. P., Sarraf, M., 2004, "Treasury Organisation: Picking the Right Model", HSBC's Guide to Cash and treasury Management in Asia Pacific 2004, pp. 139-143, viewed 10 April 2008, http://www.infosys.com/ Finacle/pdf/Tech_HSBC4.pdf

20. Watanabe, R., 1998, "Developing Taiwan into a Regional Finance and Operations Centre: a Taxation Perspective, Revenue Law Journal, vol. 8,issue 1, article 5, pp. viewed 11 April 2008, http://epublications.bond. edu.au/cgi/viewcontent.cgi? article $=1093 \&$ context $=\mathrm{rlj}$

21. Wong, P., 2007, "The reinvention of the New Asia", HSBC's Guide to Cash and Treasury Management in Asia Pacific 2007, pp. 43-47, viewed 28 March 2008, http://www.hsbcnet.com/transaction/attachments/APH/pdf/ 01 introduction.pdf

22. Zink, W. J., Griffiths, S. H., 1995 "U.S. and foreign tax implications of international treasury centers." Corporate Cashflow Magazine, Vol. 33, No. 3 


\title{
REGIONALNI RIZNIČKI CENTRI JUGOISTOČNE AZIJE - SLUČAJ BRUNEJI DARUSSALAMA
}

\begin{abstract}
Sažetak
U ovom se članku raspravlja o lokacijskim kriterijima pri osnivanju regionalnih rizničkih centara u tri države: Brunejima, Singapuru i Hong Kongu. Lokacijski kriteriji su važni činitelji za multinacionalne kompanije koje osnivaju regionalne rizničke centre izvan svojih sjedišta. Uspoređujući Bruneje s drugim vodećim azijskim financijskim centrima i lokacijama regionalnih rizničkih centara (Singapurom i Hong Kongom), utvrđuje se spremnost Bruneja za ulogu regionalnog rizničkog centra. Ova studija unapređuje razumijevanje lokacijskih kriterija za osnivanje regionalnog rizničkog centra, bez obzira na njegovu lokaciju, s obzirom da se na analizu triju azijskih zemalja ponovno primjenjuje istraživačka metoda kojom su se prethodno proučavale europske zemlje. Rezultati dobiveni korištenjem ove metode govore da Bruneji, u usporedbi sa Singapurom i Hong Kongom, imaju manjak lokacijskih kriterija.
\end{abstract}


